

\title{
Die korrespondensie van J.J. Venter met H.A.L. Hamelberg: ontleding van 'n sendingbeskouing
}

\author{
P.H. Fick \\ Skool vir Kerkwetenskappe \\ Potchefstroomkampus \\ Noordwes-Universiteit \\ POTCHEFSTROOM \\ E-pos: Rikus.Fick@nwu.ac.za
}

\section{Abstract \\ The correspondence of J.J. Venter with H.A.L. Hamelberg: an analysis of a view of mission}

The controversy regarding the view of missionary work has recurred in South African church history from time to time. This was also the case in the Reformed Church in the Orange Free State during the nineteenth century. It becomes apparent from the 1879 to 1881 correspondence of J.J. Venter with H.A.L. Hamelberg, the then Consul-General of the Free State in the Netherlands. Venter wrote to Hamelberg about his disappointment with the reverend Dirk Postma, the first minister of the Reformed Church in South Africa. According to Venter they had been misled: they had asked for a preacher and got a missionary instead. Venter's view of mission is based on a peculiar view of the doctrine of predestination: he approved of missionary work only if the fruit of election becomes apparent in the lives of the objects of the missionary work. Venter wrote particularly to Hamelberg, a "fellow-tribesman" more than a religious think-alike. This fact, as well as the correspondence reveals Venter's actual view on the doctrine of predestination and it is clearly shown in this article. Although Venter's own writings speak of a Pietistic "Busskampf", his view of mission is rather in line with orthodoxy's insistence on a structural link between church and state. Cross-cultural mission was therefore unthinkable, unless there is proof of a change in the other culture. 


\section{Opsomming}

\section{Die korrespondensie van J.J. Venter met H.A.L. Hamelberg: ontleding van 'n sendingbeskouing}

Die kwessie oor sendingbeskouing het van tyd tot tyd opslae gemaak in die Suid-Afrikaanse kerkgeskiedenis. Dit was ook die geval in die Gereformeerde Kerk in die Oranje-Vrystaat gedurende die negentiende eeu. Dit blyk duidelik uit die 1879 tot 1881 korrespondensie van J.J. Venter met H.A.L. Hamelberg, die destydse konsul-generaal van die Vrystaat in Nederland. Venter skryf aan hom oor sy teleurstelling met ds. Dirk Postma, die eerste predikant van die Gereformeerde Kerk in Suid-Afrika. Volgens Venter is hulle mislei: hulle het vir 'n leraar gevra, maar 'n sendeling gekry. Venter se siening van die sending was gegrond op 'n eienaardige siening oor die leer van die predestinasie: hy glo slegs aan sending wanneer die voorwerpe van sendingwerk vrugte van uitverkiesing vertoon. Venter skryf aan Hamelberg, 'n "stamgenoot" eerder as 'n geesgenoot in die godsdienstige sin van die woord. Hierdie feit, tesame met sy briefwisseling, verraai die eintlike rede vir sy sendingbeskouing en dit word duidelik in hierdie arikel aangetoon. Hoewel sy eie werk sprekend is van 'n Piëtistiese "Busskampf", kom sy sendingbeskouing eerder ooreen met 'n ortodoksie-aandrang vir ' $n$ verband tussen kerk en staat. Transkulturele sending is vir hom dus ondenkbaar tensy daar bewyse is van 'n verandering in die ander kultuur.

\section{Inleiding}

In die Suid-Afrikaanse kerkgeskiedenis het die kwessie oor sendingbeskouing van tyd tot tyd spanning veroorsaak - in die AfrikaansProtestantse sowel as die Rooms-Katolieke Kerk (Spoelstra, 1999: 5-12; Brain \& Denis, 1999:8-11; Odendaal, 1970:33-59; Van der Westhuizen, 1969:73-99). Dit was ook die geval aan die beginjare van die geskiedenis van die Gereformeerde Kerke in Suid-Afrika en veral in die Vrystaat. Wat laasgenoemde betref, was J.J. Venter 'n sentrale figuur. Tussen 1879 en 1881 skryf hy 'n aantal briewe aan H.A.L. Hamelberg, die destydse konsul-generaal vir die Oranje-Vrystaat in Nederland (Muller, 1907:355-362).

Venter skryf, twintig jaar na die afskeiding van die Gereformeerde Kerk, oor sy teleurstelling met ds. Dirk Postma, die stigter en eerste predikant van die Gereformeerde Kerk in Suid-Afrika. Soos uit die volgende aanhalings blyk, het dit veral oor twee sake gegaan. Hy begin egter sy eerste brief ( 7 November 1879) deur die rede te gee waarom hy juis aan Hamelberg skryf: 
Tengevolge van een vroeger schrijven door UEd. aan mij gerigt, waarbij gij mij uw bereidwilligheid te kennen gaf dat wanneer ik in Nederland of elders eenige belangrijke zaken zou te verrigting hebben gij alsdan genegen zoudt zijn voor mij zulke werkzaamheden te verrigten, daarom neem ik de vrijheid mij bij deze gelegenheid tot $u$ te wenden, in de hoop dat gij zoo goed zult zijn deze werkzaamhede aldaar te verrigting waardoor gij mij zeer zult verpligten. (Muller, 1907:355.)

Hy verwys na die spanning wat daar intussen ontstaan het tussen Postma en ds. J. Beyer wat as eerste predikant van die Gereformeerde Kerk in die Vrystaat uit Nederland gekom het. Volgens hom het Postma die lewe vir Beyer só bitter gemaak dat Beyer na sy vaderland teruggekeer het (Muller, 1907:355-356).

Vervolgens rig hy hierdie versoek aan Hamelberg:

En wijl hier slechts een Leeraar onder ons is, die inderdaad dat gevoelen deelt, en nu ons berigt is dat in Noord-Holland en Noord-Amerika, ook in deel van Scotland, alhoewel klein in getal maar nog menschen gevonden worden die met ons bij dat geloof en deze gevoel blijven staan, zoo is dan mijn vriendelike verzoek, dat gij, mijn geachte vriend, uw die moeite wille getroosten te vernemen, waar daar menschen gevonden worden die met onze genoemde gevoelen deelen en het ten sterkste uit te noodigen om met ons dies aangaande te corresponderen en nader kennis te maken, hetzij ook van welke deelen der wereld. (Muller, 1907:356.)

Dit blyk uit 'n brief van Venter (12 Julie 1880) dat Hamelberg aan hierdie versoek voldoen het (Muller, 1907:357). Laasgenoemde het die predikant van die afgeskeie gemeente in Arnhem, ds. K. Kleinendorst, van Venter se versoek vertel. Hierdie predikant het aan Venter geskryf en Venter se antwoord op hierdie brief is ook opgeneem in Muller (1907:358-361). In hierdie brief aan ds. Kleinendorst skryf Venter op 5 Januarie 1881 die volgende oor Postma:

... wij hebben hier opgemerkt, dat hij onder ons gekomen is met een Lastbrief die zich alleen bepaalt voor de blanke geloof en stamverwanten van Nederland in Zuid-Afrika; en uwe schrijven, en niet in uwe schrijven alleen, maar ook voor het Hof, is een ander Lastbrief vertoond waarbij hij zich verbonden heeft ook onder de Kaffers werkzaam te zijn. ... Wij betwisten niet dat het Woord Gods aan de gekleurden zal toegediend worden. Maar het moet geschieden naar Gods Woord en een elk partij moet hunne eigene Leeraren hebben. (Muller, 1907:359.) 
Hy spreek ook die volgende wens uit:

Wij hopen dus dat gij lieden uw onze zaken aan het hart zult trekken en ons ter zijde zullen staan. Indien die Gereformeerde Kerk in Nederland van willens is bij de zuiverheid van ons Vaderlijke Kerk te blijven, zoo openen wij onze armen en begeeren van uw, ons te willen opnemen met warme belangstelling en wenschen van harte dat een uwer Leeraren ons een bezoek willen geven om zich hier ter plaatse van de waarheid bekend te maken en ons te bemoedigen, zoodat wij hier niet een slagoffer worde van Postma en zijn aanhang maar ons moge verblijden in een weg die God ons geopend heeft van uit onze oude Vaderland. (Muller, 1907:360.)

Volgens aanhalings uit sy korrespondensie met Hamelberg kom, soos reeds vermeld, twee redes vir ontevredenheid met Postma na vore. Die eerste rede is dat Postma sy mandaat oorskry het deur ook tyd en aandag aan sending af te staan. Hy is in elk geval daarvan oortuig dat die wyse waarop sending op daardie tydstip plaasvind, nie geschiede na Gods Woord nie. 'n Sendingbeskouing gegrond op 'n eienaardige siening van die uitverkiesing het hieraan ten grondslag gelê. Sy sendingbeskouing blyk duidelik uit 'n boekie wat Venter in 1875 uitgegee het, "Wat is waarheid?". Hierdie boekie bevat sommige van sy korrespondensie met di. Jan Lion Cachet en M.P.A. Coetsee oor die sendingkwessie. In die voorrede daarvan (Venter, 1875:iii) skryf hy dat daar andermaal dwalings ingesluip het wat de grondvesten onzer dierbare kerk dreigen te schokken. Die kwessie waarna hy verwys, is die verstaan en uitvoer van Christus se sendingopdrag in Matteus 28. Hy is téén die verkondiging van die Evangelie aan heidene, behalwe wanneer er eene ware werking in die schepsels komt (Venter, 1875:9), of wanneer vruchten worden by hen openbaar (Venter, 1875:15) - anders is dit niks anders as om pêrels voor die varke te gooi nie (Venter, 1875:5). Hierdie vruchten verwys na die bewyse dat die mense onder wie daar sendingwerk gedoen word, uitverkies is. Hy betreur dit dat hy vir 'n leeraar voor de toen benarde en geplaagde gemeenten in Zuid-Afrika gevra het en dat hulle in plaas van 'n leraar, 'n sendeling gekry het (Venter, 1875:12).

Die vraag wat in hierdie artikel beantwoord wil word, is waarom Venter juis met Hamelberg oor hierdie sake korrespondeer. Is dit bloot omdat Hamelberg Venter vroeër uitgenooi het om met hom in verbinding te tree indien hy met gewigtige sake kon help? Die teoretiese stelling van hierdie artikel is dat Hamelberg baie meer as net 'n gerieflike en belangrike adres was. Hierdie "adres" verraai net 
soveel oor Venter se sendingbeskouing as die inhoud van die briewe self. Om 'n antwoord op bogenoemde vraag te kry, sal eerstens 'n oorsig gegee word oor die lewe en werk van H.A.L. Hamelberg, veral vir die tydperk wat hy in Suid-Afrika was. Dit sal gedoen word teen die agtergrond van die rol wat Nederlanders in die OranjeVrystaat se staatkundige en kulturele lewe gespeel het, ten einde Venter se "stamgenootskap" met Hamelberg uit te lig. Tweedens sal 'n oorsig oor bepaalde aspekte van J.J. Venter se lewe en werk gegee word, wat bepalend was vir sy verhouding met Hamelberg. Veral hulle politieke en godsdienstige ingesteldheid en karaktereienskappe sal onder die soeklig kom. Teen hierdie agtergrond sal uiteindelik 'n beoordeling van Venter se sendingbeskouing gegee word, gemeet aan die gereformeerde leer van die uitverkiesing.

\section{Nederlanders in die Oranje-Vrystaat}

Die Republiek van die Oranje-Vrystaat het in 1854 tot stand gekom. Aanvanklik het die Vrystaters op kulturele terrein aansluiting by die Nederlandse stamland gesoek, terwyl verskeie Nederlanders 'n toonaangewende rol in die Republiek sou speel (Malan, 1982:18). Op 15 April 1854 is per staatsordonansie vasgestel dat vanaf 1 Junie van daardie jaar die Hollandse taal as voertaal in die howe en staatsdienskantore gebruik sou word (Spies, 1941:61).

Op 15 Oktober van dieselfde jaar rig die eerste staatspresident, J.P. Hoffman, ' $n$ brief aan die koning van die Nederlande, Willem III, om hom van die totstandkoming van die Republiek te verwittig. Die volgende woorde uit hierdie brief waarmee die keuse vir die Republiek se naam verduidelik word, is merkwaardig:

... zoo vlei ik mij, dat het ook voor Uwe Majesteit niet ongevallig zijn zal, dat van dien oud-Hollandschen stam hier een tak wortelen heeft geschoten, om ook tot een volk, een andere Hollandsche natie, op te wassen, en dat deze Loot van den oud-Vaderlandschen Boom in den naam van Uw Doorluchtich Huis heet willen vereeren (Muller, 1907:47).

Die koning beantwoord hierdie brief op 14 Julie 1855. Hierin betreur hy eers die feit dat die Nederlande die politieke gesag oor SuidAfrika verloor het. Verder stem hy in om, soos versoek, 'n vlag en wapen aan die Vrystaat te skenk, en motiveer dit soos volg:

... tot herinnering aan de nauwe banden, welke tusschen onze voorvaderen en de Uwe bestonden en tot bevestiging die, welke wij wenschen, dat tusschen ons en $U$ blijven bestaan ... (Hofstede, 1876:123-125). 
Baie inwoners van die Vrystaat, volksraadslede ingesluit, was weinig geletterd en nie geskik om in openbare kantore te dien nie. Hier het die enkele Hollanders wat hulle in die Vrystaat bevind het, inderdaad hulle handig gemaak. 'n Hollandse onderwyser, Jacobus Groenendaal, was byvoorbeeld die opsteller van die Vrystaatse konstitusie en was ook die eerste staatsekretaris. Talle onderwysers, landdroste en predikante was Nederlanders en name soos J.W. Spruyt, J.A. Smellenkamp en C. van Dijk van Soelen is onlosmaaklik deel van die vroeë geskiedenis van die Vrystaat. Die Vrystaters was inderdaad baie dank verskuldig aan die "aangespoelde Hollanders" (Beyer, 1865:118) in die Republiek. Hulle het meegewerk om die burgers op nasionale gebied wakker te skud en te inspireer om saam te staan tot die behoud van hulle republikeinse onafhanklikheid (Malan, 1982:40), hoewel die Nederlanders dikwels dieselfde eise aan mense in pioniersomstandighede gestel het as aan 'n Europese volk. Hulle teenkanting teen Engelse invloed in heftige persartikels in The Friend en die Kaapse dagblaaie, Het Volksblad en De Zuid-Afrikaan, het 'n groot invloed gehad (Spies, 1941:66). Hamelberg se verskyning in die Oranje-Vrystaat moet teen hierdie agtergrond gesien word.

\section{Die lewe, werk en godsdiensinstelling van H.A.L. Hamelberg}

Hendrik Antonie Lodewijk Hamelberg is op 2 Mei 1826 in ZaltBommel (Nederland) gebore en het hom as "meester van die regte" aan die Universiteit van Utrecht bekwaam. In Oktober 1855 vertrek hy na Suid-Afrika en kom op 25 Desember 1856 in Kaapstad aan. Biografiese gegewens oor Hamelberg (1952) word uit sy dagboek gegee, tensy anders vermeld.

Nadat hy vir meer as ses maande in Kaapstad vertoef het, vertrek hy op 3 Julie 1856 na Bloemfontein en arriveer daar op 8 Augustus, waar hy dadelik met ander Nederlanders kontak maak. Die nuwe Republiek van die Oranje-Vrystaat was toe slegs twee jaar oud. Polities gesproke kon die inwoners van die Vrystaat in hierdie tyd in twee groepe verdeel word. Daar was Engelsgesinde lojaliste wat hoofsaaklik uit oorspronklike trekboere bestaan het wat hulle reeds vroeg in die negentiende eeu in die Vrystaat gevestig het en nie aan die Groot Trek deelgeneem het nie. Hulle het na inlywing by die Kaap gestreef. Daar was ook die Republikeine wat 'n sterk onafhanklikheidsgevoel gekoester het. Hulle het hoofsaaklik bestaan uit diegene wat aan die Groot Trek deelgeneem het (Malan, 1982:2). 
Op 6 Oktober 1856 is Hamelberg as staatsekretaris aangestel - 'n pos wat hy tot 12 Augustus 1857 en later weer vir 'n kort tydperk beklee het. By die geleentheid van die hoeksteenlegging van die latere Grey College (13 Oktober 1856) het hy 'n toespraak met antiEngelse sinspelings gehou, wat waarskynlik teen ds. Andrew Murray gemik was wat aan die begin die leiding met die skool geneem het en wie se pro-Britse simpatie in die Vrystaat bekend was. Die volksraad besluit daarna om jaarliks $£ 180$ tot die inrigting by te dra, maar met die uitdruklike voorbehoud dat die hooftaal Hollands sal wees (Spies, 1941:89-90). J.J. Venter was egter hewig teen hierdie regeringsteun gekant (Malan, 1929:391). Direk na sy aankoms het Hamelberg navraag gedoen oor 'n betrekking as regsgeleerde en op 18 Oktober 1856 is hy toegelaat om as advokaat en prokureur te praktiseer.

In 1857 het daar byna burgeroorlog tussen die Transvalers en Vrystaters uitgebreek weens M.W. Pretorius se aanspraak op die Vrystaat. Toe president Boshoff van die Renosterrivier terugkeer, waar die oorlog veral deur die toedoen van Paul Kruger en J.J. Venter afgewend is, was dit Hamelberg wat op 10 Junie 1857 by 'n plegtige byeenkoms in die raadsaal 'n adres aan Boshoff voorgelees en oorhandig het om hom die eer vir die "oorwinning" te gee. Kort hierna is krygshowe ingestel om die rebelle wat Pretorius gesteun het, te verhoor. Hamelberg veroordeel die vervolging só skerp dat president Boshoff dit as 'n persoonlike aanval ervaar. Toe 'n storm oor sy kop hieroor losbars, beskryf Hamelberg in The Friend van 4 Julie 1857 in 'n selfbejammerende toon hoe mense hom beskryf: ... hij is eene ezel, een stommerik, een knappe kop ... een vervloekte Hollander (Hamelberg, 1952:xiv).

Op 7 Junie 1858 is hy opnuut as staatsekretaris aangestel - 'n posisie waaruit hy moes bedank toe hy in November van dieselfde jaar tot die Volksraad verkies is en op 7 Desember sitting neem as raadslid vir Ondervalschrivier, distrik Winburg. Toe president Boshoff in November 1858 verlof van die Volksraad vra om vir enkele maande na Natal te gaan, is Hamelberg uitgenooi om as president waar te neem. Hy het dit egter van die hand gewys. By die aanvang van die volksraadsitting in Februarie 1860 het Hamelberg sy bedanking as lid van die Volksraad ingedien, omdat hy met sy kiesers verskil het oor M.W. Pretorius se verkiesing as president en oor sy verenigingspolitiek (Malan, 1929:419).

Hy het van 1 September 1860 tot 11 April 1861 waargeneem as staatsprokureur. In 1862 is hy weer deur die burgers van Philipolis en Harrismith gevra om as volksraadslid vir hulle gebied te staan, 
maar het dit ook van die hand gewys. Nadat J.H. Brand as nuwe staatspresident aangewys is, aanvaar hy egter die kandidatuur van Heidelberg (Bethulie) en is op 22 Januarie 1864 weer tot die Volksraad verkies. Hy word ook later lid van die uitvoerende raad.

In 1866 skryf hy 'n volkslied vir die Vrystaat wat deur W.F.G. Nicolai getoonset is. Onder sy aansporing is daar ook in Bloemfontein 'n monument vir al die helde van die Basoetoe-oorloë opgerig (Malan, 1982:38). Staatspresident F.W. Reitz het in 1889, hom as een vader van den Vrijstaat beskryf (Muller, 1907:xii) en daar word selfs gesê dat die skepping van die "modelrepubliek" van later jare ewe goed as die werk van Hamelberg as dié van Brand beskou kan word (Spies, 1941:xi).

Hoe langer hy in die Vrystaat was, hoe meer het Hamelberg hom aangematig om onbeskaamd en openlik skerp kritiek uit te spreek selfs teen die president en selfs terwyl hy staatsekretaris was (Spies, 1941:118). By die lees van sy dagboek leer 'n mens Hamelberg ken as iemand wat dikwels oormoedig was en 'n taamlike hoë dunk van sy eie bekwaamheid gehad het (Hamelberg, 1952:xi). Die redakteur van The Friend skroom nie om op 27 Junie 1857 dit duidelik te stel dat daar van Hamelberg se teenstanders is wat daarvan oortuig is "... that he is aiming to climb ... to the presidential chair" (Spies, 1941:120). Muller, wat Hamelberg persoonlik geken en hom later as konsul-generaal van die Oranje-Vrystaat in Nederland opgevolg het, gee die volgende karakterbeskrywing van hom: "Eenerzijds wekte zijn onafhanklijke, onverschrokken, ietwat hoekige en overkritiese aard, vooral in den beginne, onwil; anderzijds was men naijverig en kon zijn meerdere kennis en ontwikkeling niet goed verdragen." (Muller, 1907:103.) Hy was in vele opsigte 'n omstrede en in sommige kringe selfs 'n gehate figuur (Hamelberg, 1952:xii).

Dit is nie maklik om 'n duidelike beeld oor Hamelberg se godsdienstige instelling te gee nie, aangesien daar min bewyse is dat hy aktief aan die bedrywighede van 'n bepaalde kerk in Bloemfontein deelgeneem het. Hy spreek hom ook nie baie oor godsdienstige sake of sy eie belewing daarvan uit nie. Slegs by drie inskrywings in sy dagboek vind 'n mens opmerkings oor sy eie godsdiensbelewing. By sy verlowing op 4 Februarie 1860, skryf hy oor sy verloofde: "God zegen haar naar den eindloozen rijkdom zijner liefde" (Hamelberg, 1952:183), en by 20 Oktober 1861 skryf hy oor die afsterwe van hulle dogtertjie: "Die lieve ... Fanny is hedenmorgen ... door den Heer, die haar ons ... had gegeven, weder tot zich genomen, en wij loven Zijnne naam" (Hamelberg, 1952:190) en later: "Vaarwel, mijn teeder bemind kind! Een maal, als God behaagd, zal ik U weder 
zien; Hij leide en houde mij op den weg, welke tot U voert!" (Hamelberg, 1952:191). Daar is egter wel enkele ander godsdienstige verwysings uit sy dagboek aan te toon wat hier van belang is.

Toe hy in die Kaap was, meld hy dat hy 'n erediens op 20 Januarie 1856 bygewoon het in de kerk van Vogelgezang. Hy beskryf ds. Vogelgezang se preek as jammerlik (Hamelberg, 1952:52). Op sy reis na die Vrystaat woon hy 'n godsdiensoefening van ds. Murray in Ceres by. Hy beskryf die liturgie saaklik, en voeg die volgende by: "Stijl en inhoud der gebeden van de gemeenteleden lieten vrij wat te wenschen over" (Hamelberg, 1952:116). Op 30 Julie oornag hy op die plaas van Kootje Potgieter anderkant Richmond. Kootje se vrou doen die tafelgebed by die aandete wat Hamelberg beskryf as dreunerig en klagend (Hamelberg, 1952:137). Op sy terugreis na Nederland meld hy ook dat hy Biskop J.W. Colenso in Colenso hoor preek het (Hamelberg, 1952:206).

Enkele dae na sy aankoms in Bloemfontein op 8 Augustus 1856, meld hy dat hy ' $n$ erediens in die NG Kerk bygewoon en die volgende dag middagete by ds. Andrew Murray geniet het (Hamelberg, 1952:146). Die inskrywing by 4 Oktober 1856 beskryf 'n nagmaalsdiens wat hy in die NG Kerk bygewoon het. Die grootste deel van die beskrywing wy hy aan die lastigheid van vroue met skreeuende kindertjies (Hamelberg, 1952:150). Sy huwelik word op 26 Julie 1860 in Smithfield aan huis van 'n familielid van sy bruid deur ' $n$ sendeling van Karmel, Eerw. Lemue, voltrek (Hamelberg, 1952:183). Op 26 Julie 1861 word sy eerstelingdogter in sy huis gedoop deur die Wesleyaanse predikant, ds. J.G. Morrow (Hamelberg, 1952: 190). Op 12 April 1863 word sy seun aan huis van sy vriend, J.M.L. Heyligers, deur dieselfde ds. Morrow gedoop wat hy later mijn geëerde predikant noem (Hamelberg, 1952:191). Sy paaie met die NG Kerk en ds. Murray moes dus iewers voor 1860 geskei het.

Hy maak ook dikwels melding van die Vrymesselaars in die tyd toe hy aan die Kaap was voor sy vertrek na die Vrystaat. Op 11 Januarie 1856 het hy die losie De goede trouw saam met een van die lede besoek (Hamelberg, 1952:46), en op 22 Januarie die losie De goede hoop besigtig (Hamelberg, 1952:52). Op 2 April vermeld hy dat hy die optog van die vrymesselaars gesien het by geleentheid van die inwyding van die nuwe Britse losie (Hamelberg, 1952:67). Teen 3 April haal hy uitvoerig aan uit twee Kaapse koerante wat oor hierdie gebeure berig (Hamelberg, 1952:77). Op 20 Mei beskryf hy die begrafnis van 'n vrymesselaar wat hy as blote toeskouer gesien het (Hamelberg, 1952:92) en op 11 Junie beskryf hy in groot detail die roudiens van ses afgestorwe lede wat hy 
bygewoon het (Hamelberg, 1952:101-102). Toe hy in die Vrystaat was, laat hy hom op 17 Oktober 1865, op uitnodiging van sir C. Brand (die vader van president Brand) in die organisasie opneem (Hamelberg, 1952:197). Uit latere inskrywings blyk dit dat hy vinnig in hierdie organisasie opgang gemaak het.

In 1871 het hy na Nederland teruggekeer en is hy as die konsulgeneraal van die Oranje-Vrystaat aangestel - 'n taak wat hy met groot onderskeiding verrig het. Hy het op 28 September 1896 gesterf.

\section{Die lewe, werk en godsdiensinstelling van J.J. Venter}

Jacobus Johannes (Koos) Venter se naam kom van die begin van die geskiedenis van die Republiek van die Oranje-Vrystaat voor. Hy is op 22 Maart 1814 in die distrik Colesberg gebore en was een van die Colesbergse Doppers wat in die suidelike Vrystaat 'n heenkome gaan soek het. Hy is op 28 Januarie 1889 op sy plaas Broekpoort naby Bethulie oorlede en begrawe (Spoelstra, 1968:881). Reeds in 1853 het hy hom by die onafhanklikheidsgroep gevoeg en in 1854 was hy verteenwoordiger van Bloemfontein by die oorname van die Republiek en een van die ondertekenaars van die Bloemfonteinse Konvensie. By die totstandkoming van die Republiek was hy lid van die eerste Volksraad. Sedert 1855 het hy leiding geneem van die onafhanklikheidsgroep wat die ontwikkeling van dié staat, los van die Kaapkolonie of die Suid-Afrikaanse Republiek, voorgestaan het. Nadat die eerste staatspresident, J.P. Hoffman, in Februarie 1855 gedwing is om te bedank, was Venter lid van die uitvoerende kommissie wat tot Augustus die staat moes bestuur. Toe Boshoff in Junie 1859 sy bedanking as president indien, het die Volksraad J.J. Venter as sy presidensiële kandidaat aangewys, maar M.W. Pretorius is uiteindelik as president verkies.

In 1858 het Hamelberg, wat hom aanvanklik by diegene gevoeg het wat 'n federasie met die Kaapkolonie gesoek het, hom by Venter se onafhanklikheidsgroep geskaar. Hy en Venter het aktief georganiseer vir die indiening van memories by die Volksraad vir die toekoms van die OVS (Malan, 1982:30). Om die Venter-groep se saak te bevorder en om die Engelsgesinde The Friend teen te staan, is ' $n$ nuwe koerant, De Tijd, hoofsaaklik deur die toedoen van Hamelberg op die been gebring. Na die aftrede van president Pretorius in Junie 1863 is Venter as waarnemende staatspresident aangewys.

By die opvolgende presidentsverkiesing was Venter 'n kandidaat teenoor J.H. Brand. Twee van die invloedrykste koerante, The 
Friend en De Tijd met Hamelberg aan die roer, het egter Brand as kandidaat gesteun en daarmee die rug gekeer op Venter en die "konserwatiewe Dopper-element". Brand is op 5 November 1863 met 2301 stemme teenoor Venter se 1002 stemme as president verkies (Malan, 1982:33-34). Venter sou later 'n skerp kritikus van Brand se hantering van Engeland se anneksasie van die Vrystaatse diamantvelde wees. In 1869, na Brand se vertrek, is hy bo Hamelberg as waarnemende staatspresident verkies. Die volksraad het Venter ook by verskillende geleenthede as lid van 'n afvaardiging na Mosjesj gestuur (Hofstede, 1876:137). Met die uitsondering van 'n kort onderbreking was hy volksraadslid vir Bloemfontein-distrik en later van Bethulie van 1854 tot 1881 - waarskynlik die langste diens in die Vrystaatse volksraad (Spoelstra, 1968:882).

Venter was iemand wat sterk gevoel het dat die Republiek sy Hollands-Afrikaanse karakter moes behou (Spies, 1941:127). Heyligers (aangehaal in Muller, 1907:149) skryf in De Tijd van 24 Junie 1863 dat Venter sy lewe toegewy het aan die vestiging van die Vrystaat se onafhanklikheid en "immer blijken gaf van eene onbegrensde lifede jegens onze republiek". Hy word daarom as 'n "vurige patriot" beskryf wat die ideale van die behoud en uitbou van Afrikaner-Republikanisme sterk voorgestaan het (Malan, 1982:39, 88). Nadat die vlag en wapen van die Nederlandse koning ontvang is, was dit hy wat die mosie van dank by die Volksraad ingedien het (Muller, 1907:47). Sy patriotiese ingesteldheid word duidelik weerspieël in die volgende wat hy op 23 Maart 1868 in die Volksraad gesê het: "Wij moeten ons beschouwen als kinderen van een huis en eendragtig zamenwerken, om langsamerhand tot een groot rijk te komen" (Oranje-Vrystaat, 1868:19).

Die predikant in Bloemfontein, ds. Andrew Murray en Venter het tussen 1853 en 1859 gedurig in twee verskillende politieke kampe verkeer, veral wat die verhouding met die Engelse regering in die Kaap betref (Spoelstra, 1963:155).

Venter het 'n opvlieënde humeur gehad en het dikwels uit sy betrekking in die regering bedank as die volkswil negeer word. Hy het sy vurige geaardheid aan sy Hugenote-afkoms gewyt en was terselfdertyd baie trots op sy Hollandse herkoms (Spoelstra, 1963:151152). Sy geaardheid het daarvoor gesorg dat mense hom dikwels as eienaardig getipeer het. Hy word byvoorbeeld "Koning der Doppers" (vgl. Spoelstra, 1963:154, 156) of "Koning Kobus" (Van Rensburg, 1953:21) genoem na aanleiding van 'n gebeurtenis waar 'n ene A.S.J. van der Walt hom na bewering op Naval Hill as priesterkoning van die Vrystaat sou gesalf het. Muller (1907:74) noem hom 
'n "eigenaardigen, karakteristieken ouden voortrekker" (Muller, 1907:74). Hamelberg (1952) verwys enkele kere in sy dagboek na hom. Hy meld byvoorbeeld op 24 September 1857 dat hy vir Venter as prokureur opgetree het in 'n hofsaak (Hamelberg, 1952:167). Al die verwysings na Venter is egter saaklik, behalwe by die inskrywing van 17 Maart 1858, waar hy woordeliks aanhaal uit 'n toespraak van Venter wat blyke gee van sy eienaardige taalgebruik en opvlieëndheid (Hamelberg, 1952:170). Muller (1907:74) vertel ook dat hy talle briewe van Venter in sy argief het. Dit handel hoofsaaklik oor godsdienstige sake en getuig van 'n buitengewone Bybelkennis, "veel nadenken en een oorspronklijken geest".

In 'n manuskrip van 13 November 1856, beskryf Venter sy bekering. In hierdie ontboeseming kry ' $n$ mens ' $n$ besondere kyk in sy godsdiensbelewing. Hy was van kleins af geweldig onder die indruk van Christus se lyding ook vir sý sonde. Die slotsin van hierdie dokument verwoord die strekking van die hele geskrif.

Daarom was de sonde mijn tot las en smart en ik kan het niet geheel veranderd krijgen. De hart bleef soo begeerig naar sonden en ijdelheijd soodat ik geduurig te kampen heef. (Venter, 1856:8.)

Venter het 'n belangrike rol in die kerkgeskiedenis van die Vrystaat gespeel, veral wat die stigting van die Gereformeerde Kerk betref. Spoelstra (1963:157) noem hom daarom "die De Cock van die Vrystaat", omdat hy in talle opsigte in Suid-Afrika dieselfde rol gespeel het as ds. Hendrik de Cock, wat die spil was waarom die Nederlandse Afskeiding van 1834 gedraai het.

Die NG Kerk is in die Vrystaat feitlik as staatskerk erken (Beyer, 1865:62; Malan, 1982:17). Gedurende 1858 het Venter, toe hy lid van die Volksraad en die Uitvoerende Raad was, sy bedanking as lid van die NG Kerk ingedien. Op navraag van die kerkraad het hy die volgende redes daarvoor aangegee: Die evangeliese gesange, die bidure in die kerk, die kruistafels by die nagmaalsgeleenthede, die nuwe huweliksformulier en die manier van bevestiging van nuwe lidmate: dat hulle byna gedwing word om die Nagmaal by te woon, en die verklaring van die evangelie (Gerdener, 1934:172-173). Dit weerspieël by Venter, wat geen teologiese skoling gehad het nie, 'n intuïtiewe aanvoeling vir 'n gees en rigting wat in die kerk posgevat het, waarmee hy hom nie kon vereenselwig nie (Spoelstra, 1963: 159). Ten minste vyf gesinne het spoedig Venter se voorbeeld gevolg. 
Reeds in 1856 het Magaliesbergers wat beswaard was oor die kerklike situasie in Transvaal met Venter in Lydenburg ooreengekom om buite die kerkraad vir hulle 'n predikant uit Nederland te beroep, maar Paul Kruger, sy broer Douw en ander wou nie sonder die bemiddeling van die kerkraad handel nie. Daar is selfs aanduidings dat Venter self na die Christelik Afgeskeie Gereformeerde Kerk in Nederland geskryf het om 'n predikant te bekom (Spoelstra, 1968:882). 'n Versoekskrif na Nederland om "een Predikant volgens de leer der Vaderen" te stuur, is met toestemming van die Volksraad deur bemiddeling van Paul Kruger in Rustenburg opgestel. Hierdie versoekskrif is eers na Venter in Bloemfontein gestuur en toe na Nederland (Postma, 1905:219).

Op Venter se versoek het Postma na die Vrystaat gekom nadat die Gereformeerde Kerk in Februarie in Rustenburg tot stand gekom het. Hy het op 5 Mei 1859 by Venter op sy plaas oornag en die volgende aantal dae op verskillende plase verslag gedoen oor die gebeure in die Transvaal en die uitbreiding van die Gereformeerde Kerk daar (Postma, 2008:137-139). Volgens kennisgewing aan die president en die Uitvoerende Raad deur di. Dirk Postma en J.P. van der Walt, is 'n Gereformeerde gemeente op 12 Mei 1859 in die Vrystaat gestig - die dag waarop Postma die kerkraadslede bevestig het (Postma, 2008:137). Op 'n vergadering wat deur di. Postma en Venter byeengeroep is, is op 24 Junie 1859 besluit om 'n stuk grond in die distrik Vlakfontein, naamlik die plaas van Michael van der Walt, vir $£ 1500$ te koop en daarop 'n kerkdorp te stig. Dit sou "Redders Dorp", later "Reddersburg", heet. Op 21 Februarie 1861 het die Volksraad die stigtingsplek amptelik as dorp erken en op 2 November 1863 as sodanig verklaar (Malan, 1929:416). Venter was ouderling van die eerste kerkraad van Reddersburg en het, voor die koms van ds. Beyer, ook by geleentheid as voorsitter van die kerkraad opgetree (Gereformeerde Kerk Reddersburg, 18591871:1). Op 21 Januarie 1860 is die tweede Gereformeerde Kerk in die Vrystaat, naamlik Burgersdorp, op die plaas Roosterhoek gestig. Venter was as ouderling van die Gereformeerde Kerk Reddersburg daar teenwoordig (Gereformeerde Kerk Burgersdorp, 1960:13).

\section{Gevolgtrekkings}

Venter en Hamelberg het albei hard gewerk ter bevordering van die republikeinse strewe en politieke onafhanklikheid van die Vrystaat. Venter het dit as vurige patriot gedoen en Hamelberg omdat hy as Nederlander die geleentheid gesien en benut het om van diens te wees vir 'n land wat sy gawes nodig gehad het. Albei het 'n on- 
afhanklike gees en skerp intellek gehad en het nie geskroom om sterk standpunt in te neem en onverskrokke kritiek uit te spreek as dit by politieke en godsdienstige sake kom nie. Hulle het as lede van die Volksraad van die Vrystaat saam die geleentheid gehad om dit te doen en mekaar se sterk- en swakpunte te sien. Venter het veral in hierdie verband die geleentheid gehad om Hamelberg se besondere administratiewe en juridiese bekwaamhede raak te sien en te waardeer.

Dit is egter eienaardig dat Venter later vir Hamelberg skryf (wanneer laasgenoemde hom in Nederland bevind) oor 'n saak waaroor hulle die minste gemeenskaplike grond en oortuigings gehad het: 'n kerklik-godsdienstige saak. Hamelberg was immers nooit lidmaat van die Gereformeerde Kerk nie, het hom nie veel uitgespreek oor die Doppers nie en was openlik 'n ywerig lid van die Vrymesselaars. Laasgenoemde was waarskynlik die rede waarom Hamelberg Brand as presidentskandidaat bo Venter ondersteun het. Venter moes van Hamelberg se betrokkenheid by die Vrymesselary geweet het. Laasgenoemde se dagboek spreek immers van 'n openlikheid daaroor. Dit het Venter egter nie daarvan afgeskrik om oor godsdienstige sake met Hamelberg te korrespondeer nie, terwyl die Gereformeerde Kerk, waarvan Venter lidmaat was, by sy tweede algemene sinode van 1863 besluit het dat niemand tegelykertyd 'n lid van die Vrijmetselaars-genootschap én lidmaat van die Gereformeerde Kerk kon wees nie (Gereformeerde Kerk, 1863:16).

Waar Venter se godsdiensuitsprake van veel "nadenke" (Muller, 1907:74) getuig het, was dié van Hamelberg meestal saaklik van aard. Die enigste blykbare gemeenskaplike grond wat hulle ten opsigte van godsdiens gehad het, was dat hulle albei teen die Engelsgesindheid van die leraar van die NG Kerk in Bloemfontein, ds. Andrew Murray, was. Hamelberg was in feitlik alle opsigte vir Venter bloot 'n polities-kulturele kanaal waarlangs hy sy godsdienstige doelwitte kon bereik. Sy eerste skrywe(s) en dié waaraan hy saam met die Rustenburgers deel gehad het, is direk aan ampsdraers van die Christelik Afgeskeie Gereformeerde Kerk in Nederland geskryf, maar nie in hierdie geval nie. Hy skryf eerder aan Hamelberg met wie hy, toe hulle saam in die Vrystaat was, nie eintlik vriendskaps- of kerklike bande gehad het nie.

Die blote feit dat hy aan Hamelberg skryf met 'n sendingprobleem in gedagte, verraai baie oor sy sendingbeskouing. Nasionaliteit en kultuur is vir hom só belangrik, dat hy eerder aansluiting soek by 'n "stamgenoot" oor 'n bepaalde godsdienstige aspek waarby hierdie stamgenoot nie veel belang of gemeenskaplike grond het nie, as om 
daardie godsdienstige probleme op plaaslike vlak aan te pak en op te los.

Aan die een kant spreek Venter se "bekeringsdokument" van 'n sterk persoonlike, Piëtistiese Busskampf, maar aan die ander kant spreek sy houding teenoor sending van 'n ortodokse siening van die strukturele band tussen kerk en staat (vgl. Bosch, 2007:254). Vir Venter het sending waarskynlik net een moontlikheid beteken: kruiskulturele sending. Sending aan ander met 'n kultuur wat gekenmerk word deur moord en diefstal (dan 'n teken van verwerping), is onaanvaarbaar. Sy betrokkenheid by die Basotho-oorloë, wat die aanvalle van Mosjesj se impi's op die blanke bevolking in die Vrystaat moes hokslaan, het waarskynlik baie hiermee te doen gehad. Dat hy hierdie saak met 'n "stamgenoot" opneem, is dan te verstane.

Hierdie sendingbeskouing is by talle Afrikaners van sy tyd aangetref, naamlik die geloof aan die Afrikaner as ' $n$ "uitverkore volk" wat hulle moes handhaaf te midde van 'n horde ongelowiges (Du Toit, 1983: 925-927). Die leer van die uitverkiesing is dikwels in die geskiedenis op 'n baie rigiede wyse op die sendingsituasie toegepas (vgl. Medina, 1957:128, 132; Bosch, 2007:172, 258). As God individue tot die ewige lewe uitverkies het en ander tot ewige straf (die sg. predestinatio gemina), dan moet Christene dit aan Hom oorlaat om diegene te red wie Hy wil en, soos Venter dit gesien het, behoort Christene net sendingwerk te doen waar die vrugte van die uitverkiesing sigbaar is.

So 'n fatalistiese beskouing verbreek die noue band tussen uitverkiesing en voorsienigheid. Bowendien, die leer van die uitverkiesing maak nie die feit ongedaan dat die uitwendige roeping aan elkeen wat die evangelie hoor, die geleentheid bied om gered te word nie. Die mens, met sy beperkte en dikwels verdraaide kennis, het geen reg om die uitdeel van God se genade óf te bevraagteken óf te beperk nie. Boettner (1972:283-284) vra tereg die vraag: "Will any one contend that God cannot sincerely offer salvation ... unless in addition to the invitation He exerts a special influence which will induce the person to accept it?" Hy voeg die volgende belangrike opmerking daarby.

Calvinism teaches that a plan of salvation adapted to all men and adequate for the salvation of all, is freely offered to the acceptence of all, altough in the secret purpose of God He intended that it should have precisely the effect which in experience it is found to have. He designed in its adoption to save His own people, but consistently offers its benefits to all 
who are willing to receive them. More than this no anti-Calvinist can demand.

Die Gereformeerde Kerke in Suid-Afrika het teen 1923 steeds geworstel met die vraag of swart én wit binne dieselfde bediening geakkommodeer kon word (vgl. De Klerk, 1923). Dit sou nog dekades duur voordat daar 'n verandering in denkraamwerk sou kom. Mag hierdie stukkie geskiedenis uit die Oranje-Vrystaat van ouds opnuut lig werp op 'n gesonde gereformeerde siening van die verband tussen sending en uitverkiesing: die besluit van die uitverkiesing is 'n verborge besluit van God. Omdat daar geen openbaring aan die prediker gegee is oor wie onder sy gehoor verkies is of nie, is dit nie moontlik om die evangelie net aan die uitverkorenes te preek nie. Ten einde hierdie boodskap aan die uitverkorenes te verkondig, moet dit aan almal verkondig word.

\section{Geraadpleegde bronne}

BEYER, J. 1865. Journaal, gehouden van Nederland naar Zuid-Afrika (Algoabaai). Kaapstad: Solomon.

BOETTNER, L. 1972. The reformed doctrine of predestination. Philadelphia: Presbyterian \& Reformed Publishing.

BOSCH, D.J. 2007. Transforming mission: paradigm shifts in theology of mission. New York: Orbis.

BRAIN, J. \& DENIS, P., eds. 1999. The Catholic Church in contemporary Southern Africa. Pietermaritzburg: Cluster.

DE KLERK, P.J.S. 1923. Kerk en sending in Suid-Afrika. Amsterdam: Van Bottenburg.

DU TOIT, A. 1983. The myth of the Calvinist origins of Afrikaner nationalism and racial ideology. The American historical review, (88)4:920-952.

GERDENER, G.B.A. 1934. Geskiedenis van die Nederduitse Gereformeerde Kerke in Natal, Vrystaat en Transvaal. Kaapstad: Nasionale Pers.

GEREFORMEERDE KERK. 1863. Handelingen van de tweede algemeene synodale vergadering. Kaapstad: Solomon.

GEREFORMEERDE KERK BURGERSDORP. 1960. Gedenkalbum by geleentheid van die eeufees. Potchefstroom: Potchefstroom Herald.

GEREFORMEERDE KERK REDDERSBURG. Notuleboek 1859-1871. Potchefstroom: Kerkargief, Gereformeerde Kerke in Suid-Afrika. Boek 1.1.1.

HAMELBERG, H.A.L. 1952. Die dagboek van H.A.L. Hamelberg 1855-1871. Uitgegee en toegelig deur F.J. du T. Spies. Kaapstad: Van RiebeeckVereniging.

HOFSTEDE, H.J. 1876. Geschiedenis van den Oranje-Vrystaat, in verband met eene korte geschiedenis der aangrenzende kolonien, vooral der Kaapkolonie. 's Gravenhage: Thieme.

MALAN, J.H. 1929. Die opkoms van 'n republiek; of, Die geskiedenis van die Oranje-Vrystaat tot die jaar 1863. Bloemfontein: Nasionale Pers.

MALAN, S.F. 1982. Politieke strominge onder die Afrikaners van die Vrystaatse Republiek. Durban: Butterworth. 
MEDINA, J.A.O. 1957. An analysis of the missionary methods of the Puritans. The Americas, (14)2:125-134.

MULLER, H.P.N. 1907. Oude tyden in den Oranje-Vrystaat. Leiden: Brill.

ODENDAAL, A.A. 1970. Die Nederduitse Gereformeerde sending in die OranjeVrystaat (1842-1910). Stellenbosch: Universiteit van Stellenbosch. (D.Th.proefskrif.)

ORANJE-VRYSTAAT. 1868. Notule van die volksraad van die Oranje-Vrystaat. Volledig met alle bylae daarby. Kaapstad: Argiewe, publikasie-afdeling.

POSTMA, D. 1905. De geschiedenis van de stichting en ontwikkeling der Gereformeerde Kerk in Zuid Afrika. Paarl: Paarlse Drukpers.

POSTMA, D. 2008. Dagboek van Dirk Postma. Uitgegee en toegelig deur Wim Vergeer en Janet du Plooy. Pretoria: V\&R.

SPIES, F.J. DU T. 1941. Hamelberg en die Oranje-Vrystaat. Amsterdam: Swets \& Zeitlinger.

SPOELSTRA, B. 1963. Die doppers in Suid-Afrika 1760-1899. Kaapstad: Nasionale Boekhandel.

SPOELSTRA, B. 1968. Venter, Jacobus Johannes. (In De Kock, W.J., red. Suid-Afrikaanse biografiese woordeboek. Deel 1. Kaapstad: Nasionale Boekhandel. p. 844-846.)

SPOELSTRA, B. 1999. Sending vir kerk of koninkryk? Sendinggeskiedenis van die GKSA. 1869-1994. Potchefstroom: Potchefstroomse Teologiese Publikasies.

VAN DER WESTHUIZEN, H.G. 1969. Die aanvanklike houding van die Nederduitsch Hervormde Kerk ten opsigte van sending histories-krities nagegaan. Pretoria: Universiteit van Pretoria. (D.Div.-proefskrif.)

VAN RENSBURG, A.P.J. 1953. "Koning Kobus" is met ghries gesalf. Die Huisgenoot, 38(1654):21-23.

VENTER, J.J. 1856. Bekeringstuk. Band V. Potchefstroom: Argief van die Gereformeerde Kerke in Suid-Afrika.

VENTER, J.J. 1875. Wat is Waarheid? Bloemfontein: Oranjevrystaatsche Nieuwsblad.

\section{Kernbegrippe:}

Hamelberg, H.A.L.

Oranje-Vrystaat

sending

uitverkiesing

Venter, J.J.

\section{Key concepts:}

Hamelberg, H.A.L.

mission

Orange Free State

predestination

Venter, J.J. 
